\title{
DIATRIBES 1.24 E 1.25: ENFRENTANDO AS DIFICULDADES DA VIDA
}

\section{Aldo Lopes DINUCCI*}

*Doutor em Filosofia Clássica, Professor de Filosofia da UFS e colaborador do Programa de Mestrado em Filosofia da UNB. E-mail: aldodinucci@gmail.com.

Artigo submetido em abril/2015 e aceito em setembro/2015

DOI: http://dx.doi.org/10.15628/dialektike.2015.3004

\section{RESUMO}

No início da diatribe 1.24, intitulada "Como é preciso enfrentar as dificuldades", Epicteto afirma que "as dificuldades mostram o que são os homens". Nosso filósofo faz, então, uma analogia entre um treinador e um atleta, por um lado, e Deus e o ser humano, por outro. Assim, da mesma forma que um bom treinador põe oponentes potentes diante de seu atleta, devemos ver as dificuldades da vida como postas diante de nós por Deus para nos testar e fortalecer. Epicteto aprofunda essas reflexões na diatribe 1.25 , evidenciando o fundamento das reflexões da diatribe 1.24, afirmando que "o bem e o mal do homem estão na sua capacidade de escolha, [...] as demais nada são em relação a nós" (1.25.1).

PALAVRAS-CHAVE: Epicteto. Estoicismo. Dificuldades. Diatribes.

\begin{abstract}
At the beginning of discourse 1.24,a entitled " How we must face the difficulties ," Epictetus says that "the difficulties show what men are ." Our philosopher makes, then, an analogy between a coach and an athlete on the one hand, and God and the human being on the other. So, just as a good coach puts powerful opponents

before your athlete, we must see the difficulties of life as put before us by God to test us and strengthen us. Epictetus deepens these reflections on diatribe 1.25, showing the foundation of reflections of discourse 1.24 stating that "good and evil of man are in their ability to choose , [ ... ] the rest is nothing for us " ( 1.25 .1$)$.
\end{abstract}

KEYWORDS: Epictetus. Stoicism. Difficulties. Discourses.

\section{UM BREVIÁRIO DOS PRINCÍPIOS MORAIS EPICTETEANOS}

Epicteto, um dos grandes nomes do Estoicismo Imperial, entre os quais se incluem Sêneca, Musônio Rufo e Marco Aurélio, nasceu no ano 55, em Hierápolis, na Frígia, e morreu por volta de 135, em Nicópolis, antiga cidade localizada na entrada do Golfo Ambraciano, no Épiro. Filho de uma serva, recebeu um nome que era comumente dado a servos na Antiguidade e que significa "adquirido". Epicteto mesmo nada escreveu. Tal tarefa coube a Lúcio Flávio Arriano Xenofonte, cidadão romano de origem grega, que compilou (possivelmente com auxílio da taquigrafia) suas aulas em oito livros (As Diatribes de Epicteto), dos quais quatro sobrevivem, e constituiu o Encheirídion de Epicteto, um breviário 


\section{DINUCCI, Aldo Lopes (2015)}

de princípios morais epicteteanos.

No início da diatribe 1.24, intitulada "Como é preciso enfrentar as dificuldades", Epicteto afirma que "as dificuldades mostram o que são os homens" (1.24.1). Nosso filósofo faz, então, uma analogia entre um treinador e um atleta, por um lado, e Deus e o ser humano, por outro. Assim, da mesma forma que um bom treinador põe oponentes potentes diante de seu atleta, devemos ver as dificuldades da vida como postas diante de nós por Deus para nos testar e fortalecer.

Isso requer uma atitude diferenciada diante das vicissitudes. Epicteto dá um exemplo de atitude equivocada e outro de atitude acertada diante das circunstâncias difíceis. Por um lado, o batedor covarde que vai a Roma e, ao voltar, diz que por lá tudo é “terrível”. Por outro, Diógenes, o Cão, o batedor valoroso e imperturbável, que, por ser corajoso, vê as coisas sem tal olhar aterrorizado (1.24.4-5).

Assim, da mesma forma que, no capítulo 5a do Encheirídion, Epicteto nos diz que a morte não é terrível, mas é terrível a opinião segundo a qual a morte é terrível, aqui nosso estoico nos aconselha a não ver as dificuldades da vida como coisas terríveis, mas como desafios pelos quais podemos mostrar nosso valor.

Tal enfrentamento das circunstâncias supõe a aplicação do teorema acerca das coisas que são encargo nosso e das coisas que não o são (cf. Diatribes 1.1; Encheirídion 1). De acordo com esse teorema, as coisas que são encargo nosso (eph'hemin), como o juízo, o impulso, o desejo, a repulsa - atos mentais que têm como causa nós mesmos - estão no âmbito de nossa escolha (prohairesis) e são as únicas que possuem valor moral por si e que tanto determinamos quanto nos determinam. Já as coisas que não estão sob nosso encargo (ouk eph'hemin), como o nosso corpo (saudável ou não), nossa riqueza ou nossa pobreza, as pessoas que nos rodeiam, nossa fama ou obscuridade - em suma, todas as coisas que são externas à nossa faculdade de escolha - não possuem valor por si, sendo "nada" para nós, sendo indiferentes.

Cumpre notar que não são indiferentes no sentido de que não devemos nos importar com elas, mas sim de não terem valor por si, já que a partir delas tanto podemos mostrar nosso valor como o contrário, i.e. tanto podem ser bem usadas quanto mal usadas. São indiferentes, pois, como os materiais com os quais podemos construir uma casa. O bom engenheiro saberá construir com os materiais (tijolos, telhas, etc.) uma boa casa. O engenheiro incapaz não o saberá. 
Assim, temos que encarar com indiferença as coisas externas no sentido de tê-las como meios e jamais como fins. Isso implica um desprendimento em relação às coisas externas (1.24.11 ss.). Da mesma forma que, diz-nos Epicteto, ao sairmos de um navio, após uma viagem, não levamos os remos e o timão, mas somente a nossa bagagem, aquilo que realmente nos pertence, assim também, durante as dificuldades da vida, devemos estar preparados para abandonar as coisas externas quando sua posse implicar a perda de nosso valor moral. As coisas que nos rodeiam, nos diz Epicteto, são como os utensílios no quarto de uma estalagem, que não são nossos, mas estão à nossa disposição para serem bem ou mal usados na medida em que permanecermos na estalagem.

As únicas coisas que nos pertencem realmente são nossas opiniões, nossos desejos, nossos impulsos e nossa faculdade de escolha: são essas que determinam o que somos de fato.

O estoico encerra a diatribe apontando para o desapego máximo no caso do ser humano: aquele em relação à própria vida. "A porta está aberta", diz-nos ele. Quer dizer, a qualquer momento podemos abandonar essa vida. Apesar disso, devemos perseverar e não lamentar as coisas que nos ocorrem. Não devemos nos comportar como crianças mimadas que saem de um jogo quando ocorre algo que não lhes agrade (diatribe 1.24.17 ss.).

Epicteto aprofunda essas reflexões na diatribe 1.25, evidenciando o fundamento das reflexões da diatribe 1.24: "o bem e o mal do homem estão na sua capacidade de escolha, [...] as demais nada são em relação a nós" (1.25.1). Nosso filósofo observa que o conhecimento disso, que nada mais é que um modo de expressar o teorema acerca das coisas que estão sob nosso encargo e das coisas que não estão, é o suficiente para nos guiar. Aplicando esse conhecimento, poderemos agir desembaraçados e livres, já que criamos impedimentos para nós mesmos justamente quando valorizamos as coisas externas, que são por natureza escravas, i.e. que estão submetidas à vontade alheia ou às leis do Cosmos (diatribe 1.25.4. Cf. Encheirídion 1; Diatribes 1.1)

Já as coisas que estão na esfera de nossa escolha são livres e, diz-nos Epicteto (1.25.9), se nos ativermos a elas, livres igualmente seremos. Alguém pode nos fazer supor uma opinião em um embate dialético, mas ninguém pode nos impor uma opinião, i.e. ninguém pode nos fazer crer que uma opinião seja verdadeira ou falsa. $\mathrm{O}$ assentimento está totalmente sob nosso encargo.

Aqui se explica nossa tradução de eph'hemin por coisas "sob nosso encargo". Alguns tradutores vertem a expressão por "coisas sob nosso controle", o que é um erro, pois, na 


\section{DINUCCI, Aldo Lopes (2015)}

verdade, não são a priori controladas por nós. São fundamentalmente coisas que nos têm como causa, mas só estarão realmente sob nosso controle se tivermos uma atitude crítica diante das opiniões que acalentamos, testando-as. O teste de opiniões (como Epicteto exemplifica no capítulo 1 do Encheirídion) consiste em rejeitar as opiniões que atribuem valor às coisas externas e que negam valor às internas. Consiste, portanto, na aplicação do teorema acerca das coisas que estão sob nosso encargo ou não. Assim, por assim dizer, é preciso que tomemos ciência da possibilidade de sermos livres para nos libertarmos. E a liberdade, no homem, só é possível através da atitude crítica diante das próprias opiniões. Se opiniões falsas são tomadas por verdadeiras, a escolha, tomando-as como premissas, se perverte, decidindo equivocadamente e valorizando as coisas erroneamente. Se opiniões verdadeiras são selecionadas, a escolha se volta naturalmente para o que lhe convém, e atingimos a tranquilidade e a felicidade.

Assim, ao longo da diatribe 1.25, Epicteto nos dá exemplos de indivíduos que acalentam opiniões que valorizam as coisas externas, criando obstáculos para si mesmos.

Epicteto encerra a diatribe reconhecendo o caráter aparentemente paradoxal do teorema acerca das coisas sob nosso encargo ou não, observando que esse caráter é comum às teses filosóficas e científicas. Nosso filósofo exemplifica isso com a punção no olho efetuada por um médico para curar a catarata, pelo que se tem que "ferir" o olho para curá-lo. Assim, muitas verdades filosóficas e científicas, distantes do senso comum, são paradoxais apenas em relação a este.

\section{UMA TRADUÇÃO}

Realizamos a tradução diretamente a partir do texto grego e, a seguir, cotejamos nosso trabalho com as melhores traduções disponíveis das Diatribes de Epicteto, dando especial atenção às de Georg Long (1890), Oldfather (1928), Dobbin (2006) e de Souilhé (1962).

\subsection{DIATRIBE 1.24 - COMO É PRECISO ENFRENTAR AS DIFICULDADES ${ }^{1}$}

(1) As dificuldades mostram o que são os homens. De hoje em diante, quando uma

${ }^{1}$ Peristaseis: acusativo plural de peristasis.

Dialektiké. Ano 2, v. 2, out 2015, p. 131-142 | Revista de Filosofia 


\section{DINUCCI, Aldo Lopes (2015)}

dificuldade suceder, lembra que Deus, como um treinador, te pôs para lutar com um jovem duro $^{2}$.

- (2) Para que? - diz alguém.

- Para que te tornes vencedor dos Jogos Olímpicos ${ }^{3}$, o que não ocorre sem suor. Para mim, ninguém parece ter melhor dificuldade que tu tens, se quiseres, como o atleta, fazer uso de um jovem lutador. (3) Presentemente, enviamos um batedor ${ }^{4}$ a Roma. Mas ninguém envia um batedor covarde, para que, tão somente escute um ruído e veja uma sombra em algum lugar, venha correndo, agitado, dizendo que os inimigos chegaram. (4) Do mesmo modo, agora, se também tu fores e nos disseres que “Terríveis estão as coisas em Roma, terrível é a morte, terrível é o exílio, terrível é a ofensa, terrível é a pobreza, (5) fugi, homens, os inimigos chegaram!", dir-te-emos "Vai embora, tu profetizaste a ti mesmo. Nós cometemos só esta falta: ter enviado um batedor de tal qualidade".

(6) Diógenes, batedor que foi despachado antes de ti, deu-nos <outras> respostas. Ele diz que a morte não é um mal, pois não é infames. Diz que "má reputação" é um ruído produzido por homens loucos. (7) E esse batedor anunciou tais coisas sobre a dor, sobre o prazer, sobre a pobreza: que estar nu é melhor do que <vestir> qualquer toga pretexta ${ }^{6}$, que não há leito mais macio que dormir sobre a terra nua ${ }^{7}$. (8) E dá demonstração sobre cada coisa <dessas> : a coragem ${ }^{8}$, a ausência de agitação na alma $^{9}$, a $\operatorname{liberdade~}^{10} \mathrm{e}$, em seguida, seu diminuto corpo, resplandecente e urdido. (9) Diz ele: "Nenhum inimigo está próximo: tudo está pleno de paz ${ }^{11 ” . ~ C o m o, ~ D i o ́ g e n e s ? ~ " V e ̂, ~ d i z ~ e l e, ~ a l g o ~ m e ~ a t i n g i u ? ~ A l g o ~ m e ~ f e r i u ? ~ F u g i ~ d e ~}$ algo?" (10) Desse modo é preciso ser um batedor. Porém, tu, ao vires a nós, diz-nos isso e aquilo. Não irás de novo e olharás com mais precisão e sem covardia?

- (11) Então o que farei?

- O que fazes quando desembarcas de um navio? Não levas contigo o timão nem os remos, não é? Mas levas as tuas coisas, o lécito ${ }^{12}$, o alforje $^{13}$. Assim, agora, se tiveres em

\footnotetext{
${ }^{2}$ Trachei: dativo masculino de trachys

${ }^{3}$ Quanto à referência aos Jogos Olímpicos e à luta, cf. Encheirídion 19a; 29.2; 51.2.

${ }^{4}$ Kataskopos.

${ }^{5}$ Cf. Diógenes Laércio 6.43.

${ }^{6}$ Periporphyros: a toga praetexta ou laticlavia.

${ }^{7}$ Cf. Estobeu, 4.29.19.

${ }^{8}$ Tarsos.

${ }^{9}$ Ataraxia.

${ }^{10}$ Eleutheria.

${ }^{11}$ Panta eirenes gemei.

12 Lekythos.

${ }^{13}$ Pera: bolsa de couro usada para levar provisões.
} 
mente as tuas próprias coisas, nunca reclames a posse das alheias. (12) Alguém te diz:

- Tira a toga senatorial ${ }^{14}$.

-Toma-a!

- Tira também essa, <a toga dos magistrados $>15$ !

- Cá estou apenas com a toga ${ }^{16}$.

- Tira a toga!

- Cá estou nu.

- Contudo, ainda me provocas inveja.

- Toma, pois, meu diminuto corpo por inteiro.

Ainda temo esse homem a quem posso lançar meu corpo?

- (14) Porém, ele não me fará seu herdeiro.

- E então? Olvidei que nenhuma dessas coisas é minha? Como, pois, as chamo "minhas"? Como a cama na estalagem ${ }^{17}$. Desse modo, se o estalajadeiro, ao morrer, deixar para ti a cama, ótimo; mas se deixar para outro, tu buscarás uma nova. (15) Se não encontrares, dormirás no chão, confiante e roncando, e lembrando que as tragédias têm lugar entre os ricos, entre os reis, entre os tiranos. Nenhum pobre participa de uma tragédia, a não ser como corista ${ }^{18}$. (16) E os reis começam pela prosperidade:

Ponde guirlandas de flores na casa! ${ }^{19}$

Então, no terceiro ou quarto ato:

Ai de mim, Citéron ${ }^{20}$, por que me recebeste $?^{21}$

(17) Prisioneiro, onde estão as guirlandas de flores? Onde o diadema? Teus guarda$\operatorname{costas}^{22}$ em nada são úteis? Assim, quando te acercares de algum desses <personagens>, lembra-te disto: que te acercas de uma figura trágica, não de um ator, mas do próprio Édipo.

- Porém, fulano é feliz ${ }^{23}$, pois anda de lá para cá com os muitos. Eu mesmo me

\footnotetext{
14 Platysemos: como se chamava, em grego, a tunica laticlavia, que era usada sem cinto, para melhor exposição do já referido latus clavus.

${ }^{15}$ Seguimos aqui a sugestão de Souilhé. A toga augusticlavia era usada pelos magistrados. A retirada das sucessivas togas significa a supressão de todas as honras públicas e não, é claro, que alguém as esteja usando simultaneamente.

${ }^{16}$ Imation: como já dito acima, esse é o termo grego para a toga romana, peça de vestuário de origem etrusca que era usada exclusivamente pelos cidadãos romanos.

${ }^{17}$ Cf. Encheirídion 11.

${ }^{18}$ Choreutes: participante do coro, que, na tragédia clássica, como personagem coletiva, canta partes do drama.

${ }^{19}$ Verso de tragédia desconhecida.

${ }^{20}$ Citéron: montanha consagrada a Dioniso, onde Édipo, quando bebê, foi exposto.

${ }^{21}$ Verso de Édipo Rei, 1390 (Sófocles).

${ }^{22}$ Doryphoroi: nominativo plural de doryphoros.

${ }^{23}$ Makarios.
} 
alinho com os muitos e com os muitos ando de lá para cá.

Eis o principal: lembra-te que a porta está aberta ${ }^{24}$. Não te tornes mais covarde que as crianças, que, quando algo não lhes agrada, dizem "Não brinco mais", dizendo tu também, quando apresentar-se uma coisa tal, "Não mais brincarei”, e saindo. Mas se ficares, não te lamentes $^{25}$.

\subsection{DIATRIBE 1.25 - ACERCA DO MESMO}

(1) Se essas coisas são verdadeiras, e se não somos $\operatorname{lerdos}^{26}$ e não estamos fingindo ${ }^{27}$ que o bem e o mal do homem estão na sua capacidade de escolha, e que as demais nada são em relação a nós, por que nos agitamos, por que temos medo? (2) Ocupamo-nos com essas coisas a respeito das quais ninguém tem poder; não nos importamos com aquelas sobre as quais os outros têm poder - então qual é o nosso problema?

- (3) Dá-me ordens ${ }^{28}$ !

- Que ordens eu te darei? Zeus já não te deu as ordens? Não te deu as tuas coisas desimpedidas e desembaraçadas? E as que não são tuas não são impedidas e entravadas? Aqui chegaste com certas ordens. (4) De que decreto ${ }^{29}<$ tens precisão $>$ ainda? "Vela pelas tuas coisas por todos os meios", "Não almejes as de outrem”, “É < obra> tua ser leal 30 ", "É <obra> tua ser digno ${ }^{31}$ ". Quem pode tirar essas coisas de ti? Quem te impedirá de usá-las senão tu mesmo? E como tu impedirás a ti mesmo? Quando te ocupas das coisas que não são tuas, perdes as tuas. (5) Possuindo tais conselhos e ordens da parte de Zeus, quais tu queres ainda da minha parte? Sou melhor que ele? Mais digno de confiança ${ }^{32}$ ? Se velares por eles, de quais outros precisarás ainda? Mas ele não te ordenou essas coisas? (6) Toma as pré-noções, toma as demonstrações dos filósofos, toma o que ouviste muitas vezes, toma o que disseste para ti mesmo, toma o que leste, toma o que praticaste.

(7) Então por quanto tempo tens velado belamente por essas coisas, sem abandonar o

\footnotetext{
${ }^{24}$ Ou seja: "Podes morrer da vida quando quiseres".

${ }^{25} \mathrm{O}$ verbo aqui é threneo, que significa literalmente "cantar uma canção triste".

${ }^{26} \mathrm{O}$ verbo aqui, que aparece essa única vez em toda a obra de Epicteto, é blakeuo.

${ }^{27} \mathrm{O}$ verbo aqui é hypokrinomai, que significa primariamente "separar gradualmente, submeter a inquérito, cumprir um papel", donde (metaforicamente) "fingir".

$28 \mathrm{O}$ verbo aqui é entello.

${ }^{29}$ Diatagma.

${ }^{30}$ Pistos.

31 Aidemon.

${ }^{32}$ Axiopistoteros.
} 
jogo? (8) Pelo tempo em que te conduziste bem. Na Saturnália, os reis são escolhidos por sorteio, pois assim decidiu-se jogar o jogo. O rei comanda ${ }^{33}$ : "Bebe; mistura o vinho; canta; vai lá; vem cá!" Eu obedeço ${ }^{34}$ para que o jogo não termine por meu intermédio ${ }^{35}$.

- (9) Porém, tu, sê de opinião ${ }^{36}$ de que estás mal.

- Não o serei. E quem me pode constranger a ser de tal opinião?

(10) De novo, decidimos encenar as histórias de Agamenon e Aquiles. O que se dispõe como Agamenon me diz:

- Vai, Aquiles, e leva Briseida ${ }^{37}$ à força.

- (11) Vou.

- Volta.

- Volto.

Pois é preciso comportar-se na vida do mesmo modo que nos comportamos em relação aos argumentos hipotéticos.

- <Aceita por hipótese > que "É noite".

- Que seja.

- E então? É dia?

- Não. Pois aceitei a hipótese de que é noite.

- (12) Aceita por hipótese que supões que é noite

- Que seja.

- Sê de opinião $0^{38}$ que é noite.

- (13) Isso não segue da hipótese.

Do mesmo modo também aqui:

- <Toma por hipótese> que és desafortunado.

- Certo.

- Portanto, és não-afortunado.

- Sim.

- E então? És infeliz?

$-\mathrm{Sim}$

\footnotetext{
${ }^{33} \mathrm{O}$ verbo aqui é prostasso.

${ }^{34} \mathrm{O}$ verbo aqui é hypalouo.

${ }^{35}$ Cf. Diatribes 1.25 (final); 2.16.37; Horácio, Epístolas, 1.14.36.

${ }^{36} \mathrm{O}$ verbo aqui é hypolambano.

${ }^{37}$ Troiana que foi sequestrada por Aquiles durante a guerra de Tróia e que foi tomada de Aquiles por Agamenon.

${ }^{38}$ Hypolabe: imperativo de hypolambano, que aqui significa precisamente "ser de opinião que".
} 
- Mas sê também de opinião de que estás em maus lençóis.

- Isso não segue da hipótese. E um outro ${ }^{39}$ me impede <de crer em tal opinião>.

(14) Entretanto, por quanto tempo é preciso dar ouvidos ${ }^{40}$ a tais <hipóteses $>$ ? Por quanto me for útil. Isto é: por quanto tempo eu conserve o que é apropriado ${ }^{41}$ e adequado $^{42}$. (15) Além disso, há os que são muito amargos e de estômago muito sensível que dizem "Eu não posso jantar na casa desse <homem>, pois não o suporto descrevendo todo dia, em detalhes, como lutou em Mísia: "Descrever-te-ei, irmão, em detalhe, como cheguei a uma colina e, (16) em seguida, sofri um cerco"” . Mas outro diz: "Eu quero antes jantar e ouvir quantas coisas ele desejar tagarelar". (17) Compara ${ }^{43}$ tu também essas avaliações ${ }^{44}$. Só não ajas pesadamente nem oprimido, nem como se estivesses em maus lençóis ${ }^{45}$. Pois ninguém te constrange <a fazer isso>. (18) Há fumaça na casa? Se a quantidade é moderada, permaneço; se é excessiva, saio. É preciso, pois, lembrar-se sempre disto: a porta está aberta.

- (19) Não mores em Nicópolis.

- Não moro.

- Nem em Atenas.

- Nem em Atenas.

- Nem em Roma.

- Nem em Roma.

- Mora em Giaros ${ }^{46}$.

- (20) Moro.

Porém, para mim, morar em Giaros se me afigura "muita fumaça". Retiro-me para onde ninguém me impedirá de viver. Pois essa casa está aberta para todos. (21) E a última sobrecasaca $^{47}$, quer dizer, meu diminuto corpo, dele para cima ninguém tem poder sobre mim. (22) Por isso Demétrio disse a Nero: “Tu me ameaças com a morte; mas a natureza ameaça a

\footnotetext{
${ }^{39}$ Georg Long, Souilhé e Dobbin dizem estar aí subentendido Zeus. Mas pode ser também o hegemonikón, a faculdade diretriz.

${ }^{40}$ Hypakousteon: adjetivo verbal de Hypakouo ("dar ouvidos").

${ }^{41}$ Prepon.

${ }^{42}$ Katallelon.

${ }^{43} \mathrm{O}$ verbo aqui é synkrino, que significa primariamente "combinar, juntar, agregar", donde "comparar".

${ }^{44}$ Axias é acusativo plural de axia, que normalmente traduzimos por "valor", mas que, aqui, significa algo como "apreciação do valor", donde "avaliação".

${ }^{45}$ Cf. Encheirídion 25.

${ }^{46}$ Giaros (atual Yioura) é uma ilha desolada do arquipélago grego das Cíclades. Miserável desde a Antiguidade, habitada por uns poucos pescadores, tornou-se posteriormente destino de vários banidos pelos imperadores romanos. Musônio Rufo, professor de Epicteto, foi banido para Giaros, por Nero, em 65, retornando a Roma em 68, após a ascensão de Galba.
}

${ }^{47}$ Chitonarion. 
ti”. (23) Contudo, se eu admirar meu diminuto corpo, entrego-me como escravo. Se eu admirar minhas diminutas posses, entrego-me como escravo. (24) Pois imediatamente evidencio $^{48}$ que sou passível de captura ${ }^{49}$ por alguém. Quando a serpente contrai a cabeça, digo “Atinge o que ela protege!". Do mesmo modo, sabe tu também que o teu senhor marchará sobre o que quiseres proteger. (25) Lembrando-te dessas coisas, quem ainda adularás ou temerás?

- (26) Mas quero sentar onde sentam os senadores!

- Vês que tu por ti mesmo te pões em aperto ${ }^{50}$, que tu afliges a ti mesmo.

- (27) Porém, como, de outro modo, contemplarei belamente <o espetáculo> no anfiteatro?

- Homem, não contemples o espetáculo e não te oprimas. Qual é o problema? Ou espera um pouco e, quando terminar o espetáculo ${ }^{51}$, senta no lugar dos senadores e toma um banho de sol $^{52}$. (28) Em geral, pois, lembra-te disto: nós mesmos nos afligimos, nós mesmos nos colocamos em aperto - isto é: as nossas opiniões nos afligem e nos põe em aperto. (29) O que é ser ofendido? Põe-te diante de uma pedra e ofende-a. E o que farás? Se alguém escutar como uma pedra, que vantagem há para quem ofende? Mas se possuir uma fraqueza, o que ofende, ao ofender, terá um meio de acesso ${ }^{53}$ e, então, conseguirá algo.

- (30) Arranca e rasga <a toga > dele!

- Por que dizes "dele"? Toma a toga, rasga-a!

- Fiz-te um ultraje ${ }^{54}$ !

(31) Que isso seja um bem para ti! Sócrates praticava essas coisas, por isso mantinha sempre o mesmo semblante. Porém, nós queremos antes tudo pôr em prática ${ }^{55}$ e praticar que nos tornarmos de tal modo desembaraçados e livres.

- (32) Os filósofos dizem paradoxos.

\footnotetext{
${ }^{48} \mathrm{O}$ verbo aqui é deloo.

${ }^{49}$ Alotos: esse termo ocorre apenas uma vez em Epicteto.

${ }^{50} \mathrm{O}$ termo aqui é stenochoria, que significa literalmente "espaço apertado" e metaforicamente "dificuldade" daí "aperto".

51 Theoria.

52 O verbo aqui é eliazo ("tomar banho de sol"). Epicteto pode estar fazendo um jogo de palavras com eliazomai, que significa "sentar-se na corte de Helieia" (a suprema corte da Atenas antiga).

${ }_{53}$ A palavra aqui é epibatra, que significa literalmente "escada".

${ }^{54}$ Hybris.

$55 \mathrm{O}$ verbo aqui é askeo, que, como vemos por essa passagem, tem, para Epicteto, o mesmo sentido de meletao ("praticar").
} 
Mas nas outras artes não há paradoxos? E o que é mais paradoxal que efetuar uma punção no olho de alguém para que este veja ${ }^{56}$ ? Se isso é dito a alguém sem experiência em medicina, este não riria do que fala? (33) Assim, não se admira que também na filosofia muitas verdades se afigurem paradoxais aos inexperientes.

\section{REFERÊNCIAS}

DINUCCI, A.; JULIEN, A. O Encheiridion de Epicteto. Coimbra: Imprensa de Coimbra, 2014.

DINUCCI, A. Fragmentos menores de Caio Musônio Rufo; Gaius Musonius Rufus Fragmenta Minora. In: Trans/Form/Ação. vol.35 n.3 Marília, 2012.

Diatribes 12 e 13 de Musônio Rufo: Sobre coisas relativas a Afrodite e casamento.

In: Revista Crítica Histórica, v. 7, p. 348, 2013. Disponível em:

http://www.revista.ufal.br/criticahistorica/index.php?option=com_content\&view=article\&id= 178:diatribes $12 \mathrm{e} 13 \mathrm{dem}$ soniorufo\&catid $=87$ :documentacao $\&$ Itemid $=63$

. Apresentação e tradução da Diatribe 1.1 de Epicteto. IN: Revista ARCHAI. As origens do pensamento ocidental, v. 13, p. 143-157, 2014. Disponível em:

http://seer.bce.unb.br/index.php/archai/article/view/11000

Apresentação e tradução da Diatribe de Epicteto 1.8. In: Prometeus. Filosofia em Revista, v. 7, p. 289-295, 2014. Disponível em:

http://seer.ufs.br/index.php/prometeus/article/view/2845

Tradução e comentário à Diatribe de Epicteto 1.2: como manter o caráter próprio em todas as ocasiões. In: Veredas da História, v. 5, p. 197-208, 2012. Disponível em: http://veredasdahistoria.kea.kinghost.net/edicao8/15_TRADUCAO_COMENTADA_197208.pdf

Introdução ao Manual de Epicteto. 3 ed. São Cristóvão: EdiUfS, 2012.

DINUCCI, A. L.; BRITO, R. P. Tradução e Apresentação da Diatribe de Epicteto 1.5. In: Revista de Filosofia Antiga (USP. Ed. português), v. 8, p. 116, 2014. Disponível em: http://www.revistas.usp.br/filosofiaantiga/article/view/81223/pdf_12

DIÓGENES LAÉRCIO. Lives of Eminent Philosophers, vol. I, II. Trad. R. D. Hicks. Harvard: Loeb Classical Library, 1925.

EPICTETO. Entretiens. Livre I. Trad. Joseph Souilhé. Paris: Les Belles Lettres, 1956.

Epictetus Discourses book I. Trad. Dobbin. Oxford: Clarendon, 2008.

${ }^{56}$ Como observa Georg Long, trata-se de referência à cirurgia de catarata.

Dialektiké. Ano 2, v. 2, out 2015, p. 131-142 | Revista de Filosofia 
O Encheirídion de Epicteto. Trad. Aldo Dinucci; Alfredo Julien. São Cristóvão: EdiUFS, 2012. (Edição Bilíngue)

Testemunhos e Fragmentos. Trad. Aldo Dinucci; Alfredo Julien. São Cristóvão: EdiUFS, 2008.

EPICTETUS. The Discourses of Epictetus as reported by Arrian; Fragments; Encheiridion. Trad. Oldfather. Harvard: Loeb, 1928.

HORÁCIO. Satires, Epistles, Ars Poetica. Trad. H. R. Fairclough. Harvard: Loeb, 1926.

LONG, Georg. Discourses of Epictetus, with Encheiridion and fragments. Londres: Georg Bell and sons, 1890. 
DINUCCI (2015)

dialektiké 